\title{
PENGARUH PEMBERIAN TERAPI GENERALIS DALAM MENGATASI ANSIETAS KELUARGA PASIEN HEMODIALISA
}

\author{
Qurrotul Aeni ${ }^{1}$, Riani Pradara Jati ${ }^{1}$ \\ ${ }^{1}$ Program Studi Ilmu Keperawatan, Sekolah Tinggi Ilmu Kesehatan Kendal \\ E-mail : Qurrotul80@gmail.com
}

\begin{abstract}
ABSTRAK
Hemodialisa adalah suatu tindakan terapi pengganti ginjal yang telah rusak, yaitu memindahkan darah pasien dari tubuhnya melalui dialiser yang terjadi secara difusi dan ultrafiltrasi. Pasien yang menjalani kegiatan secara terus menerus dapat mengalami beberapa masalah psikologis diantaranya ansietas. Penelitian bertujuan untuk mengetahui pengaruh terapi generalis dalam mengatasi ansietas keluarga pasien hemodialisa di RSUD Dr.H. Soewondo Kendal sebelum dan sesudah pemberian terapi generalis ansietas. Metode penelitian menggunakan quasi eksperimen dengan pre post test without control group.Menggunakan kuesioner DASS (Depression Anxiety Stress Scale) yang terdiri 14 pertanyaan terkait ansietas. Sampel penelitian berjumlah 60 keluarga. Hasil penelitian Karakteristik responden sebagaian besar responden dalam rentang usia 26 - 60 tahun, berjenis kelamin perempuan, dengan tingkat pendidikan responden sebagian besar SLTA dan mayoritas responden tidak bekerja. Hubungan antara klien dan keluarga lebih didominasi hubungan dengan pasangan hidup. Kemampuan keluarga dalam upaya mengatasi ansietas pretes mean 9,32 (SD 5,53) sedangkan pada saat post test 11,28 mean (SD 5,61) dengan nilai $p=$ value 0,002, yang menunjukan bahwa adanya perubahan kemampuan keluarga dalam mengatasi ansietas melalui terapi generalis ansietas. Saran bagi semua keluarga khususnya untuk dapat menerapkan terapi generalis yang telah diajarkan untuk membantu mengatasi ansietas pada anggota keluarga yang menjalani terapi hemodialisa
\end{abstract}

Kata kunci : Ansietas, keluarga pasien hemodialisis, terapi general ansietas

\section{THE EFFECT OF GENERALIST THERAPY IN OVERCOMING FAMILY ANXIETY OF HEMODIALYSIS PATIENTS}

\begin{abstract}
Hemodialysis is an act of renal replacement therapy that has been damaged, which is to move the patient's blood from his body through a dialiser which occurs by diffusion and ultrafiltration. Patients who undergo activities continuously can experience some psychological problems including anxiety. The study aimed to determine the effect of generalist therapy in overcoming family anxiety of hemodialysis patients in Dr.H Hospital. Soewondo Kendal before and after giving anxiety generalist therapy. The research method used quasi experiment with pre post test without control group. Using the DASS questionnaire (Depression Anxiety Stress Scale) consisting of 14 questions related to anxiety. The research sample amounted to 60 families. Research results Respondents' characteristics were the majority of respondents in the age range 26-60 years, female, with the education level of the respondents mostly high school and the majority of respondents did not work. Relationships between clients and families are more dominated by relationships with spouses. Family ability in an effort to overcome the anxiety pretest mean 9.32 (SD 5.53) while at post test 11.28 mean (SD 5.61) with a value of $p=$ value 0.002 , which indicates that there is a change in the ability of families to overcome anxiety through anxiety generalist therapy. Suggestions for all families in particular to be able to apply generalist therapy that has been taught to help overcome anxiety in family members undergoing hemodialysis therapy.
\end{abstract}

Keywords: Anxiety, family of hemodialysis patients, general therapy anxiety.

\section{PENDAHULUAN}

Hemodialisa adalah suatu tindakan terapi pengganti ginjal yang telah rusak atau terjadinya gangguan ginjal kronik (Cahyaningsih, 2008). Terapi hemodialisa merupakan suatu cara yang dilakukan untuk mengeluarkan zat terlarut yang tidak diinginkan melalui difusi dan hemofiltrasi untuk mengeluarkan air yang terlarut yang tidak diinginkan (OCallaghan, 2007). 
Hemodialisa ini dilakukan bila fungsi ginjal untuk membuang zat - zat sisa metabolik yang beracun dan kelebihan cairan dari tubuh sudah sangat menurun (Vitahealth, 2008). Proses hemodialisa tersebut memindahkan darah pasien dari tubuhnya melalui dialiser yang terjadi secara difusi dan ultrafiltrasi, kemudian darah kembali lagi ke dalam tubuh pasien. Pasien akan menjalani kegiatan secara terus menerus seumur hidupnya, serta banyak menyebabkan kematian (Baradevo, Dayrit, \& Siswandi, 2008).

World Health Organization (WHO) (2008), melaporkn bahwa 57 juta kematian di dunia disebabkan oleh penyakit Gagal Ginjal Kronik (GGK). Laporan The United States Renal Data System (USRDS, 2013) menunjukkan prevalensi rate pasien dengan penyakit ginjal kronik di Amerika Serikat pada tahun 2011 sebesar 1.9011 per 1 juta penduduk. Di Indonesia berdasarkan survei dari perhimpunan nefrologi Indonesia (Pernefri, 2009) terdapat 18 juta orang menderita penyakit ginjal kronik. Data dari Indonesian Renal Registry (2012) pada tahun 2009, tercatat 12.900 pasien gagal ginjal kronis yang menjalani hemodialisa, dan pada tahun 2011 sebanyak 22.304 pasien.

Kasus gagal ginjal di Jawa Tengah yang tertinggi adalah kota Surakarta terdapat 1497 kasus $(25,22 \%)$ dan yang kedua dalah Kabupaten Sukoharjo yaitu 742 kasus $(12,50 \%)$ dan di Kabupaten Kendal sebanyak 60 pasien gagal ginjal dan yang menjalani terapi hemodialisa di RSUD Dr. H. Soewondo Kendal diambil dari rata - rata data 3 bulan (Data rekam Medis RSUD Dr. H.Soewondo Kendal bulan September-November 2016).

Pasien dengan Gagal Ginjal Kronis, yang menjalani terapi hemodialisa pada akhirnya akan mengalami perasaan kehilangan karena kehidupan normalnya terganggu dengan kegiatan hemodialisis (Alam \& Hadibroto, 2007). Penyakit ini merupakan salah satu penyakit yang tidak menular yang telah menjadi masalah kesehatan masyarakat di dunia maupun di Indonesia yang dapat menyerang setiap orang baik pria maupun wanita tanpa memandang tingkat ekonomi (Kemenkes RI, 2010). Pasien yang menjalani hemodialisa mengalami beberapa masalah psikologis antara lain ansietas, stres, dan depresi (Wrdani; Livana: Sofa, 2015).

Ansietas adalah kekhawatiran yang tidak jelas atau menyebar, yang berkaitan dengan perasaan tidak pasti dan tidak berdaya serta tidak memiliki objek spesifik. Ansietas dialami secara subyektif dan di komunikasikan secara interpersonal. Ansietas berbeda dengan rasa takut yang merupakan penilaian intelektual terhadap bahaya (Stuart, 2009). Pendapat lain menyatakan bahwa takut sebenarnya tidak bisa dibedakan dengan ansietas karena individu yang merasa takut atau mengalami pola respon perilaku, fisiologis dan emosional dalam rentang yang sama (Videbeck, 2008).

Prevalensi ansietas di negara berkembang pada usia dewasa sebanyak 50\% (Videback, 2008). Prevalensi gangguan mental emosional di Indonesia yang didalamnya termasuk ansietas mencapai6\%. Kota bogor merupakan kota yang ada di provinsi Jawa barat, dimana prevalensi ansietas yangmerupakan bagian dari gangguan mental emosional nilainya cukup tinggi, yaitu sebesar 28,1\% (Riskesdas, 2013). Ansietas yang terjadi salah satunya disebabkan karena sedang dirawat dirumah sakit, sehingga membutuhkan pelayanan kesehatan jiwa secara holistik dan komprehensif.

Fallon, 2006 dalam (Slametiningsih, 2012) pelayanan pada Pasien dalam menjalani terapi hemodialisa yang mengalami ansietas sebesar $74,6 \%$. Ansietas terjadi dikarenakan kurangnya pengetahuan, besarnya biaya yang harus dikeluarkan dan adanya informasi yang mengatakan bahwa tindakantersebut harus dilakukan seumur hidup. Hal ini didukung oleh penelitian sebelumnya yang dilakukan oleh Sugianti (2011), di ruang hemodialisa Rumkial Dr. Ramelan Surabaya, mengenai lama dan frekuensi pasien GGK yang menjalani hemodialisa, pasien yang mengalami ansietas berat sebesar $33 \%$, ansietas sedang sebesar $45 \%$, ansiets ringan sebesar $22 \%$.

Arosa (2014), menunjukkan distribusi responden berdasarkan tingkat ansietas terhadap keluarga yang mendampingi keluarganya menjalani terapi hemodialisa, dapat diketahui dari 52 responden sebanyak 28 orang $(53,8 \%)$ responden mengalami tingkat ansietas kategori sedang, yang mengalami tingkat ansietas kategori berat sebanyak 12 orang $(23,1 \%)$, dan yang mengalami tingkat 
ansietas kategori ringan sebanyak 5 orang $(9,6 \%)$ dan yang tidak mengalami ansietas 7 orang $(13,5 \%)$.dan membutuhkan penanganan terapi.

Penerapan terapi generalis ansietas menghasilkan perubahan kemampuan relaksasi nafas dalam, Mampu melakukan distraksi, Mampu melakukan teknik 5 jari serta Mampu melakukan spiritual dari pre test $38 \%$ kemudian saat post test menjadi 95\% mengalami peningkatan 57\%. Livana (2015) dengan adanya pendampingan keluarga yang baik. Keluarga dapat menjadi faktor yang sangat berpengaruh dan dapat menentukan keyakinan dan nilai kesehatan individu tentang program pengobatan yang diterima. Hasil penelitian Jumaini (2014), dari interview dengan keluarga dan pasiensetelah diberikan terapi generalis terapi lima jari dan relaksasi menunjukkan bahwa tingkat ansietas keluarga yang anggota keluarganya menjalani terapi hemodialisa diketahui bahwa responden mengalami tingkat ansietas ringan sebanyak 12 orang $(23,1 \%)$ dan tingkat ansietas sedang sampi berat sebanyak 40 orang $(76,9 \%)$.

Tingkat ansietas berdasarkan studi pendahuluan yang dilakukan peneliti atas ijin dari pihak rumah sakit, serta dibantu dengan beberapa perawat diruagan hemodialisa menunjukan data jumlah serta jadwal kehadiran terapi pasien. Menggunakan alat ukur kuesioner DASS 42 (Depression Anxiety Stress Scale) pertama kali digunakan pada tahun 1995, yang diperkenalkan oleh Lovibond \& Lovibond dan sekarang telah menjadi standar dalam pengukuran depresi, ansietas dan stres. Peneliti menggunakan kuesioner DASS 42 karena kuesiner ini sudah sering digunakan untuk penelitianuntuk mengukur ansietas pasien dan keluarga peneliti mendapatkan 10 pasien dan 12 keluarga pasien di ruang Hemodialisa RSUD Dr. H. Soewondo Kendal pada tanggal 27 Mei 2016 tentang tingkat ansietas pada keluarga pasien hemodialisa didapatkan hasil dari 4 pasien tersebut mengalami ansietas sedang, dan 6 mengalami ansietas ringan. Adapun jumlah pasien yang menjalani hemodialiasa selama 3 bulan terakhir mulai September - November 2016 rata - rata sebanyak 60 pasien., serta kurang pahamnya pasien dan keluarga terkait dengan penyakit, serta cara mengatasi perasaan ansietas tersebut. Berdasarkan latar belakang diatas dan dari hasil penelitian terkait sehingga peneliti tertarik untuk mnegetahui gambaran tingkat ansietas keluarga pada pasien dengan terapi hemodialisa dengan mengadakan penelitian dengan judul "Pengaruh terapi generalis dalam mengatasi ansietas keluarga pasien hemodialisa di RSUD Dr.H. Soewondo Kendal".

\section{METODE}

Jenis penelitian yang dilakukan pada penelitian ini adalah penelitian quasi eksperimen dengan pre post test without control group. Populasi dan sampel dalam penelitian ini adalah semua keluarga pasien hemodialisis di ruang Hemodialisa RSUD Dr.H Soewondo Kendal dengan jumlah 60 keluarga. Teknik sampling, teknik pengambilan sampel dalam penelitian ini menggunakan metode total sampling, dengan waktu pelaksaanya pada bulan Agustus 2018. Data dianalisis menggunakan uji chi square.

\section{HASIL}

Tabel 1 Menunjukan hasil analis bahwa berbagai karakteristik responden ditemukan bahwa sebagaian besar responden daulam rentang usia 26 - 60 tahun yaitu $41(66,3 \%)$, sebanyak $48 \quad(80,0 \%)$ berjenis kelamin perempuan, dengan tingkat pendidikan responden sebagian besar SLTA 39 (65\%), dan $32(53,3 \%)$ responden tidak bekerja namun 39 $(65,0 \%)$ mereka memiliki penghasilan > UMK Kab.Kendal hal ini dikarenakan rata-rata mereka mendapat setoran dari pasangan hidup/orangtua/anak/saudara yang lain yang bekerja baik diluar maupun dildalam negeri yang hampir pasti setiap bulanya mereka dapatkan, adapun Hubungan antara klien dan keluarga keluarga lebih didominasi hubungan dengan pasanagn hidup yaitu 23 ( 38, 8\%) dan sebagai orang tua menduduki peringkat kedua dengan $18(30,0 \%)$. 
Tabel 1

Karakteristik responden $(n=60)$

\begin{tabular}{lcc}
\hline \multicolumn{1}{c}{ Variabel } & $\mathrm{f}$ & $\%$ \\
\hline Usia & & \\
a. Usia rentang (18-25 tahun) & 19 & $31,7 \%$ \\
b. usia rentang (26-60 tahun) & 41 & $66,3 \%$ \\
\hline Jenis Kelamin & & \\
a. Laki-laki & 12 & $20,0 \%$ \\
b. Perempuan & 48 & $80,0 \%$ \\
\hline Pekerjaan & & \\
a. Bekerja & 28 & $46,7 \%$ \\
b. Tidak Bekerja & 32 & $53,3 \%$ \\
\hline Hubungan Dengan Klien & & \\
a. Orang Tua & 18 & $30,0 \%$ \\
b. Pasangan Hidup & 23 & $38,8 \%$ \\
c. Anak & 10 & $16,7 \%$ \\
d. Sepupu & 7 & $11,7 \%$ \\
e. Kakek/Nenek & 1 & $1,7 \%$ \\
f. Cucu & 1 & $1,7 \%$
\end{tabular}

\section{PEMBAHASAN}

Jumlah responden yang mengalami ansietas berjumlah 60 dan mayoritas mengalami ansietas tingkat sedang, sehingga memerlukan adanya tindakan terapi generaluis ansietas Pengaruh Penerapan terapi generalis Terhadap Tingkat Ansietas Keluarga Pasien Hemodialisa pada pre test dan postesDari 60 mengalami perubahan lebih baik dengan $\mathrm{P}=$ value 0.002.Hasil penerapan terapi generalis ansietas ini mendukung penelitaian Hikmawati, Mubin, dan Livana (2013) tentang pengaruh teknik lima jari terhadap tingkat stres keluarga dalam merawat kliengangguan jiwa. Hasil penulisan tersebut menunjukkan bahwa ada pengaruh teknik lima jariterhadap respons fisik sebesar $60 \%$. Berdasarkan hasil penulisan tersebut dan hasil penerapan terapigeneralis pada klien ansietas dengan penyakit fisik dapat penulis simpulkan bahwa kemampuanklien dalam mengatasi ansietas dengan tindakan keperawatan terapi generalis ansietas meningkatsebesar 57 klien.Meskipun penulis tidak mengidentifikasi tingkat ansietas klien dengan skalaindikator Depression Anxiety Stress Scale 42 (DASS 42.Hal ini yang menjadi keterbatasan darikarya ilmiah akhir ini sehingga penulis tidak mengetahui tingkat ansietas klien setelah pemberianterapi generalis.

Penelitian ini dilakukan sebanyak 4 kali pertemuan dengan reponden yag berbeda, menyesuaikan jadwal terapi responden, setiap pertemuan dilakukan selama 15-30 menit, didampingi oleh keluarga, yang menjadi target dalam penelitian. Pelaksanaan terapi ini diawali dengan mengenalkan pada responden tentang ansietas (pengertian, peyebab, tanda gejala, proses terjadinya hingga bagaimana cara untuk menanganinya) dengan diajarkan tehnik relaksasi nafas dalam, distraksi dan tehnik lima jari, dengan media yang digunakan yaitu leaflet, booklet serta ceramah dan diskusi demonstrasi terlebih dahulu. Selama proses terapi pasien dan keluarga mengikuti dengan baik, kooperatif dan mau mendemonstrasikan kembali cara pemberian terapi generalis yang diajarkan, yaitu tehnik relaksasi, distraksi serta terapi lima jari. Hasil penelitian ini didukung oleh penelitian Banon, Dalami dan Noorkasiani (2014) Tentang Efektifitas terapi hipnotis Lima jari untuk menurunkan tingkat ansietas pasien hipertensi. Hasil penelitian tersebut menunjukan adanya penurunan tingkat ansietas pada pasien dengan hipertensi yaitu $\mathrm{p}=$ value 0,019 . Didukung pula oleh penelitian Nugroho (2016) Tentang Intervensi Tehnik Relaksasi Lima JariTerhadap Fatigue Klien Ca Mamae Di RS Tugurejo Semarang dengan 53 responden Hasil menunjukan bahwa kualitas tidur berhubugan yang bermakna dengan fatigue $\mathrm{p}=$ value 0,004 dan pemberian teknik lima jari berpengaruh pada peningkatan istirahat tidur dan penurunan fatigue dengan $\mathrm{p}=$ value 0,000 .

Slametiningsih dalam penelitianya Pengaruh Logoterapi salah satu dari terapi generalis Individu Paradoxical Intention Terhadap 
Penurunan Ansietas pada Pasien Gagal Ginjal Kronik (GGK) Yang Menjalani Terapi Hemodialisa disimpulkan bahwa ada penurunan baik secara fisiologis, kognitif, prilaku dan emosional, yang salah satunya dapat menurunkan ansietas setelah diberikan logoterapi individual paradoxical intention $\mathrm{p}=$ value 0,000 , sama halnya pada hasil penelitian ini setelah diberikan terapi lima jari, relaksasi serta imajinasi terbimbing ansietas pada responden.

Pemberian terapi relaksasi dzikir salah satu dari terapi generalis oleh Patimah, Suryani dan Nuraeni (2015) terbukti dapat mengurangi ansietas pada 17 responden diruang hemodialisa dr.Slamet garut selama 2 hari dilakukan 2sesi masing-masing selama 25 menit dengan hasil $\mathrm{p}=$ value 0,000 . Pemberian terapi Generalis untuk mengurangi ansietas baik dengan terapi relaksasi distraksi nafas dalam dan terapi lima jari, serta terapi dzikir terbukti dapat mengurangi ansietas pada pasien baik penelitian yang menggunakan kelompok kontrol maupun tidak ini terbukti bahwa dengan ketenagan manajemen emosi yang baik secara otomatis dapat membantu ataupun mengurangi beban pikiran yang dapat menimbulkan ansietas pada diri seseorang.

\section{SIMPULAN DAN SARAN Simpulan}

Ada pengaruh yang signifikan pada intervensi keperawatan keluarga pasien hemodialisa untuk mengatasi ansietas keluarga melalui terapi generalis anxietas dengan baik $\mathrm{p}=$ vaue 0,002 melalui terapi generalis anxietas ini dilakukan dengan tehnik relaksasi distraksi nafas dalam dan terapi lima jari pada keluarga pasien dengan gagal ginjal diruang hemodialisa.

\section{Saran}

Diharapkan keluarga pasien hemodialisa mampu menerapkan terapi generalis secara kontinyu dalam mengatasi ansietasnya serta dapat membantu mengurangi ansietas anggota keluarga yang sedang menjalani terapi hemodialisis.

\section{DAFTAR PUSTAKA}

Andriani, T., Mubin, F., Livana, PH. (2012). Gambaran Tingkat Stres Pada Keluarga Yang Memiliki Penderita Gangguan
Jiwa Di RSUD Dr. H. Soewondo Kendal. Skripsi. Tidak dipublikasikan

Arosa, Fyl Asro (2014). Hubungan Tingkat Pengetahuan Keluarga Tentang Hemodialisa dengan Tingkat Ansietas Keluarga yang Anggota Keluarganya Menjalani Hemodialisa. Program Studi Ilmu Keperawatan Universitas Riau

Cahyaningsih, N. D (2008). Hemodialisa (cuci darah). Jogjakarta: Mitra Cendekia Press

Endang Banon, Ermawati Dalami, Noorkasiani (2014). Tentang Efektifitas terapi hipnotis Lima jari untuk menurunkan tingkat ansietas pasien hipertensi. Vol 2 No 3 Novemberr 2014, hal 24-33

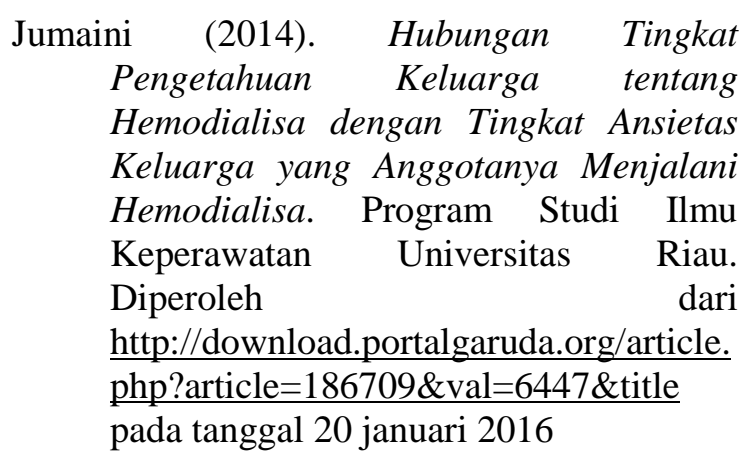

Kemenkes RI. (2013). Riset Kesehatan Dasar:RISKESDAS. Jakarta: Balitbang Kemenkes

Lin Patimah, Suryani, Aan Nuraeni (2015) Pengaruh Relaksasi Dzikir Terhadap Tingkat Ansietas Pasien Gagal Ginjal Kronis yang Menjalani Hemodialisa Stikes Karsa husada Garut, Volume 3 nomor 1 April 2015

O' Callaghan, C (2007).At a Glance Sistem Ginjal, edisi 2.Jakarta : Erlangga

Rekam medis pasien tahun 2015-2016 RSUD Dr.H.Soewondo Kendal

Slametiningsih (2012). Pengaruh Logoterapi Individu Pardoxical Intention Terhadap Penurunan Ansietas Pada Pasien Gagal Ginjal Kronik Yang Menjalani Terapi Hemodialisa Di RS Cempaka Putih Jakarta Pusat. Program Studi Magister Keperawatan Peminatan Keperawatan Jiwa Depok diperoleh dari 
http://lontar.ui.ac.id/file?=digital/203061 56-T30971+-+Pengaruh+logoterapi.pdf pada tanggal 18 November 2016

Stuart, G.W (2009). Principles and practice of psychiatric nursing(9th edition). St.Louis: mosby.

Videbeck, S.I (2008). Psychiatric of Nursing. Philadelphia: F.A

WHO (2008).Integrated Chronic Disease Prevention and Control.www.who.int 